\title{
Noble gas based temperature reconstruction on a Swiss stalagmite from the last glacial-interglacial transition and its comparison with other climate records
}

Article

Accepted Version

Creative Commons: Attribution-Noncommercial-No Derivative Works 4.0

Ghadiri, E., Vogel, N., Brennwald, M. S., Maden, C., Häuselmann, A. D., Fleitmann, D., Cheng, H. and Kipfer, R. (2018) Noble gas based temperature reconstruction on a Swiss stalagmite from the last glacial-interglacial transition and its comparison with other climate records. Earth and Planetary Science Letters, 495. pp. 192-201. ISSN 0012-821X doi: https://doi.org/10.1016/j.epsl.2018.05.019 Available at https://centaur.reading.ac.uk/77456/

It is advisable to refer to the publisher's version if you intend to cite from the work. See Guidance on citing.

To link to this article DOI: http://dx.doi.org/10.1016/j.epsl.2018.05.019

Publisher: Elsevier

All outputs in CentAUR are protected by Intellectual Property Rights law, including copyright law. Copyright and IPR is retained by the creators or other copyright holders. Terms and conditions for use of this material are defined in the End User Agreement. 


\section{www.reading.ac.uk/centaur}

\section{CentAUR}

Central Archive at the University of Reading

Reading's research outputs online 
1 Noble gas based temperature reconstruction on a Swiss stalagmite from the

2 last glacial - interglacial transition and its comparison with other climate

3

4

5

6

7

8

9

10

11

12

13

14

15

\section{records}

Elaheh Ghadiri a, b, Nadia Vogel a , Matthias S. Brennwald a, Colin Maden ${ }^{\mathrm{c}}$, Anamaria D. Häuselmann d,e, Dominik Fleitmann ${ }^{\text {d, e, f, }}$, Hai Cheng ${ }^{\text {g, h }}$, Rolf Kipfer ${ }^{\text {a, b, c }}$

${ }^{\text {a }}$ Eawag, Swiss Federal Institute of Aquatic Science and Technology, Department of Water Resources and Drinking Water, Überlandstrasse 133, 8600 Dübendorf, Switzerland, (*Correspondence: elaheh.ghadiri@eawag.ch)

${ }^{\mathrm{b}}$ ETH Zurich, Department of Environmental System Sciences, Institute of Biogeochemistry and Pollutant Dynamics, Universitätstrasse 16, 8092 Zürich, Switzerland

${ }^{\mathrm{c}}$ ETH Zurich, Department of Earth Sciences, Institute of Geochemistry and Petrology, Clausiusstrasse 25, 8092 Zurich, Switzerland

${ }^{\mathrm{d}}$ Institute of Geological Sciences, University of Bern, 3012 Bern, Switzerland

${ }^{\mathrm{e}}$ Oeschger Centre for Climate Change Research, University of Bern, 3012 Bern, Switzerland

${ }^{\mathrm{f}}$ University of Reading, Department of Archaeology, School of Human and Environmental Sciences, Whiteknights, Reading, UK

${ }^{\mathrm{g}}$ Department of Geology and Geophysics, University of Minnesota, Minneapolis, MN 55455, USA

${ }^{\text {h }}$ Institute of Global Environmental Change, Xi' an Jiaotong University, Xi' an 710049, China 
Here we present the results of a first application of a "Combined Vacuum Crushing and Sieving (CVCS)" system to determine past (cave / soil) temperatures from dissolved noble gas concentrations in stalagmite samples grown under 'cold' climatic conditions (e.g. close to freezing point of water) during the last glacial-interglacial transition. To establish noble gas temperatures (NGTs) also for stalagmites grown in cold regions, we applied the CVCS system to samples from stalagmite M2 precipitated in the Milandre Cave, located in the Swiss Jura Mountains. The investigated stalagmite M2 covers the Allerød - Younger Dryas - Holocene transitions. Noble gas temperatures are determined by using a new algorithm based on noble gas and water abundances and not from concentrations. Noble gas results indicate annual mean temperatures in the Milandre Cave were $2.2 \pm 1.8^{\circ} \mathrm{C}$ during the late stages of the Allerød, then dropping to $0_{(-)}^{+} 2.6^{\circ} \mathrm{C}$ at the onset of the Younger Dryas. Such temperatures indicate conditions near to the freezing point of water during the first part of the Younger Dryas. During the last part of the Younger Dryas, the temperature increased to $6.3 \pm 2.3{ }^{\circ} \mathrm{C}$. No early Holocene temperature could be determined due the non-detectable water abundances in these samples, however one late Holocene sample indicates a cave temperature of $8.7 \pm 2.7^{\circ} \mathrm{C}$ which is close to the present day annual mean temperature. NGTs estimated for the Allerød - Younger Dryas - Holocene are in good agreement with paleo-temperature reconstructions from geochemical and biological proxies in lake sediments. The observed deviations between the different paleo-temperature reconstructions are minor if the according temperatures are rescaled to annual mean temperatures and are primarily attributed to the chronological tuning of the different records. As in other stalagmites, NGT reconstructions of the recently precipitated stalagmite ('young') samples again are biased, most likely due to diffusive gas loss during sample processing. We speculate that a reduced retentivity of noble gases during experimental sample processing is a general feature of recently precipitated stalagmite fabrics. Therefore, the recently precipitated stalagmite samples do not allow the reliable NGT determination given the currently available experimental methods. Nevertheless, this study makes the case that noble gas thermometry can be applied to stalagmites for physically based paleo-temperature reconstruction, also for stalagmites grown during cold climatic conditions. 
46 Keywords: Noble gas thermometry, Stalagmite, Fluid inclusion, Younger Dryas, Allerød. 


\section{Introduction}

Stalagmites are recognized to represent excellent climate archives, which cover long time periods of up to $10^{6}$ a and can be dated with high precision (Fairchild and Baker, 2012). A wide range of analytical methods - mainly stable isotope analyses - are routinely applied to deduce direct or indirect information about climatic and environmental conditions. These commonly applied methods have been compiled in comprehensive papers (e.g. Fairchild and Baker, 2012; Meckler et al., 2015). Recently, novel methods have been developed and applied to obtain temperatures from stalagmites, such as clumped isotope thermometry (Affek et al., 2008), D / H ratios of water inclusion in stalagmite (Zhang et al., 2008; Affolter et al., 2014), liquid-vapor homogenization of stalagmite fluid inclusions (Krüger et al., 2011) and noble gas temperature determination of fluid inclusions (Kluge et al., 2008; Vogel et al., 2013a; Meckler et al., 2015). Such temperature estimates are of particular importance, because cave temperatures are usually not affected by seasonal temperature variations and correspond to mean annual air temperatures (Fairchild et al., 2006; Kluge et al., 2008). Therefore, noble gas analysis (e.g. noble gas thermometry) permit to reconstruct the annual mean temperature (Brennwald et al., 2013a), complementing many seasonal temperature reconstructions derived from other terrestrial climate archives. Likewise, noble gas thermometry allows to disentangle temperature from other environmental processes that also affect the calcite precipitated during stalagmite growth, e.g. hydrological signals are being recorded in the stalagmites' stable isotope composition (Vogel et al., 2013b; Affolter et al., 2015).

With the development of a combined vacuum crushing and sieving system (CVCS; Vogel et al., 2013a), it has become possible to determine paleo-temperatures from the noble gases dissolved in minute amounts of water in speleothem inclusions. The concept of this so-called noble gas temperature (NGT) is based on the temperature, pressure, and salinity-dependent solubility of atmospheric noble gases in water, whereby the concentrations of noble gases are constant in air on a scale of up to about $10^{6} \mathrm{a}$ (Brennwald et al., 2013b). Although the method is routinely applied to 'large' water samples from lakes and groundwaters, i.e. $~ 20-50 \mathrm{~g}$ (Kipfer et al., 2002), the application of noble gas thermometry to stalagmites is experimentally challenging, as the amounts of stalagmite water and the associated noble gas abundances are very small (water $\leq 1 \mathrm{mg}$ and noble gas abundance $\leq \mathrm{n} \mathrm{Mol}$ ) and thus difficult to 
analyze (e.g. Brennwald et al., 2013a). Furthermore, noble gases of water-filled inclusions convey information on paleo-temperatures whereas the noble gases in air-filled inclusions do not contain any information because such inclusions host only unfractionated noble gases in atmospheric abundance. Since noble gas abundances in stalagmites are commonly dominated by noble gases from air inclusions (Kluge et al., 2008; Scheidegger et al. 2010; Brennwald et al 2013a), air-filled inclusions pose severe experimental and conceptual problems to reconstruct cave temperatures. The separation of water inclusions from air inclusions is therefore a prerequisite for reconstructing paleo-temperatures (Brennwald et al., 2013a; Kluge et al., 2008; Scheidegger et al., 2010; Scheidegger et al., 2011; Vogel et al., $2013 a)$. The CVCS system reduces the amount of air in calcite samples and therefore delivers meaningful paleotemperature estimates. It also allows to obtain hydrological information by measuring the water and noble gas amounts extracted from the crushed stalagmite samples. The new CVCS system was successfully applied on samples from tropical stalagmites from Yemen (Vogel et al., 2013a) and Borneo (Meckler et al., 2015). But up to now, the CVCS crushing method has never been applied on stalagmites which grew under 'cold' climatic conditions (e.g. close to freezing point of water) such as the PleistoceneHolocene transition. We consider this study as a critical methodological analysis to assess and validate noble gas thermometry on stalagmite that formed under cold climate conditions.

Here we present the application of the CVCS technique to determine noble gas concentrations and water content for stalagmite M2, a specimen that grew under cold climate conditions in the Milandre Cave (Jura Mountains, Switzerland) during the time period from the end of the last glacial to the present (Table 1). The determined NGTs are directly calculated from the deduced noble gas and water abundances and compared to other independent temperature estimates from lake sediments derived indirectly from other proxies. We make the case that the NGTs generally agree with the other indirect temperature reconstructions which for the time being is the only possible approach to compare temperature reconstruction from different methodologies and we then discuss potential causes for the observed temperature deviations.

\section{Experimental methods}

\subsection{The study area and sample description}


Stalagmite M2 was collected in 2007 and found actively growing (fresh calcite was forming on top of

102

103

104

105

106

107

108

109

110

111

112

113

114 the sample) from the Galerie des Fistuleusses in the Milandre cave (400 m a.s.1.) in Switzerland (47 $29^{\prime}$ $\mathrm{N}, 07^{\circ} 01^{\prime} \mathrm{E}$ ). The Milandre cave (Fig. 1) extends for more than $10 \mathrm{~km}$ total and is embedded in the St. Ursanne Limestone Formation in the Swiss Plateau Jura (Braillard, 2006). Continuous temperature measured between 2008 and 2010 at four locations within the cave show stable temperatures, which were hardly influenced by seasonal variations and remain constant at around $9.56 \pm 0.15{ }^{\circ} \mathrm{C}$ (Schmassmann, 2010; Spadin et al., 2015). Additional cave air temperature measurements conducted between 2012 and 2013 in close proximity to the M2 sampling site are around $9.8 \pm 0.2{ }^{\circ} \mathrm{C}$ (Affolter et al., 2015).

During the same time interval (2008 - 2010), the annual mean air temperature at the meteorological station of Fahy (596 m a.s.1., $10 \mathrm{~km} \mathrm{SW}$ from Milandre) is around $9.0^{\circ} \mathrm{C}$. Using the mean annual lapse rate of $0.5^{\circ} \mathrm{C} / 100 \mathrm{~m}$ obtained from forty stations in Switzerland between 1991 and 2013 (data source Meteo Schweiz, http://www.meteoschweiz.admin.ch), this translates into a mean annual air temperature outside Milandre Cave of around $10{ }^{\circ} \mathrm{C}$. Therefore, within half a degree the current Milandre cave air temperatures are in good agreement with the annual mean temperature of the region outside of the cave.

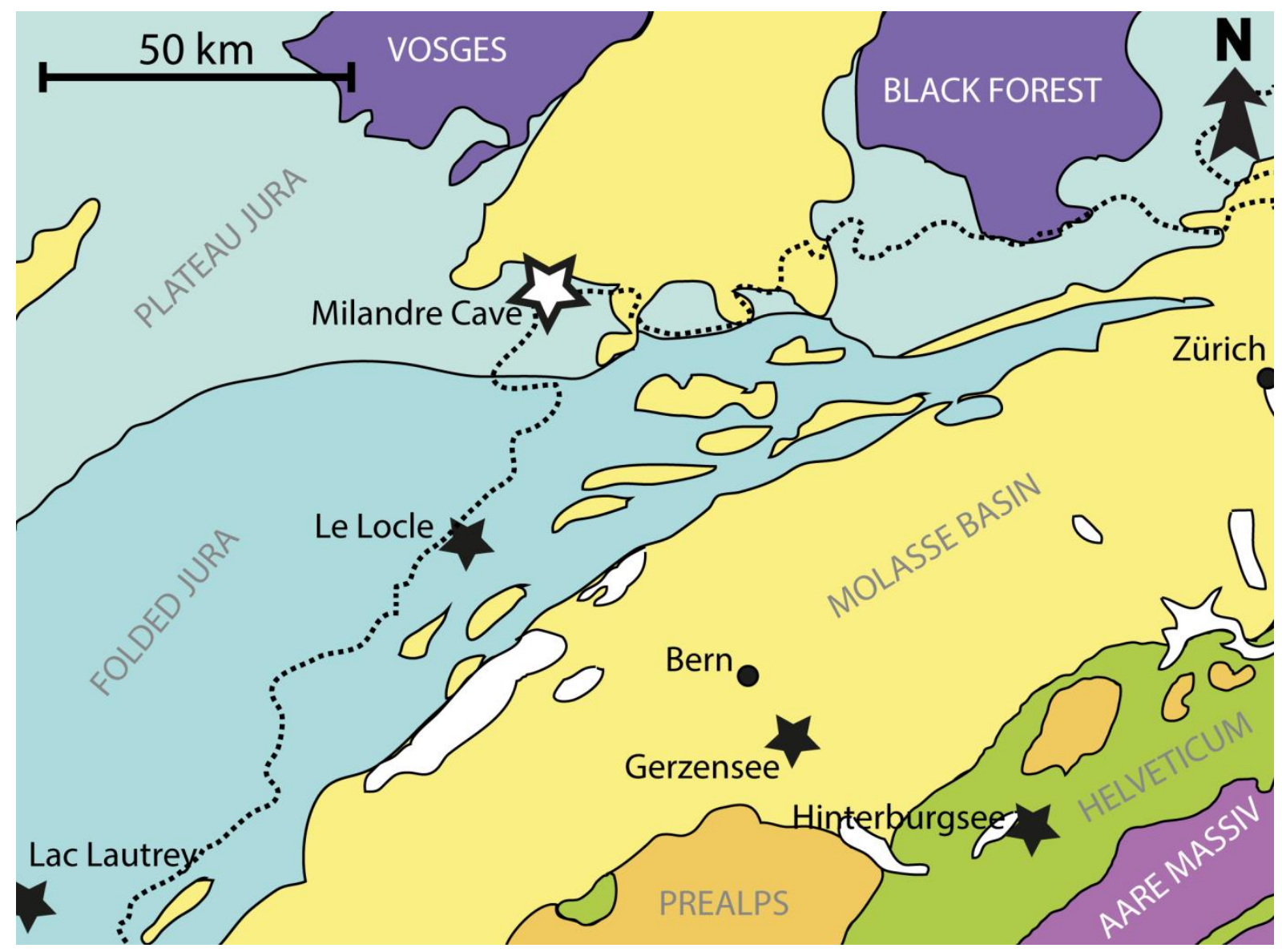


Fig. 1. Simplified geological map of NW Switzerland. The dashed line delineates the NW border of Switzerland. Stars indicate other locations in Switzerland (Le Locle, Gerzensee, Hinterburgsee) and France (Lac Lautrey) where paleo-climatic information is available and to which our NGT reconstructions are compared.

The $256 \mathrm{~mm}$ long stalagmite M2 is composed of columnar calcite and shows several clay layers in its upper $140 \mathrm{~mm}$ (Fig. 2a). The Allerød - Younger Dryas - early Holocene transitions are covered in the lower part of M2, between 154 and $195 \mathrm{~mm}$ depth, and are well visible in the oxygen isotope record. Isotopic shifts of $2.2 \%$ and $3.5 \%$ VPDB were measured at the transition between Allerød - Younger Dryas and Younger Dryas - early Holocene, respectively. The shift of oxygen isotopes in Milandre cave is interpreted as an indicator of temperature changes at the cave, with a positive shift indicating warmer temperatures (Schmassmann, 2010; Häuselmann, 2015). The sampling locations of the calcite used for $\mathrm{U} /$ Th dating are indicated by the black arrows in Fig. 2b. The results of the U / Th dating of M2 calcite are presented in Table 1 and Fig. 2b. Schmassmann (2010) dates the calcite precipitated at $128 \mathrm{~mm}$ in M2 stalagmite $(8.1 \pm 0.5 \mathrm{ka} \mathrm{BP}, \mathrm{BP}=1950)$. For the calcite precipitated between 151 and $265 \mathrm{~mm}$ depth, an age model was built using the COPRA algorithm (Breitenbach et al., 2012), and for the calcite precipitated between 0 and $144 \mathrm{~mm}$ depth we used linear age interpolation $(0 \mathrm{~mm}: 0 \mathrm{a}, 144 \mathrm{~mm}: 9.31 \pm$ $0.15 \mathrm{ka} \mathrm{BP}$ ). Unfortunately, the use of interpolation and the presence of multiple hiati do not allow us to build a strong age model for the top $151 \mathrm{~mm}$ of sample, although the age measured by Schmassmann (2010) agrees well with our rather rough age model. The calcite precipitated at a growth rate between 0.026 and $0.051 \mathrm{~mm} / \mathrm{a}$ between $14.39 \mathrm{ka} \mathrm{BP}$ and $11.32 \mathrm{ka} \mathrm{BP}$. After $9.31 \mathrm{ka}$ BP we estimate a mean growth rate of $\sim 0.015 \mathrm{~mm} / \mathrm{a}$. 
136 Table 1

$137 \mathrm{U} / \mathrm{Th}$ dating results of stalagmite M2.

\begin{tabular}{|c|c|c|c|c|c|c|c|c|c|c|}
\hline $\begin{array}{l}\text { Sample } \\
\text { Number }\end{array}$ & $\begin{array}{l}\text { Depth } \\
(\mathrm{mm})\end{array}$ & $\begin{array}{l}{ }^{238} \mathrm{U} \\
(\mathrm{ppb})\end{array}$ & $\begin{array}{l}{ }^{232} \mathrm{Th} \\
(\mathrm{ppt})\end{array}$ & $\begin{array}{l}{ }^{230} \mathrm{Th} /{ }^{232} \mathrm{Th} \\
\left(\times 10^{-6}\right)\end{array}$ & $\begin{array}{c}\delta^{234} U^{*} \\
\text { (measured) }\end{array}$ & $\begin{array}{c}{ }^{230} \mathrm{Th} / \text { / }^{238} \mathrm{U} \\
(\mathrm{Bq} / \mathrm{Bq})\end{array}$ & $\begin{array}{l}{ }^{230} \text { Th Age (a) } \\
\text { (uncorrected) }\end{array}$ & $\begin{array}{l}{ }^{230} \text { Th Age (a) } \\
\text { (corrected) }\end{array}$ & $\begin{array}{l}\delta^{234} \mathrm{U}_{\text {Initiale }} \text { ** } \\
\text { (corrected) }\end{array}$ & $\begin{array}{l}{ }^{230} \text { Th Age (a BP) } \\
\text { (corrected) }\end{array}$ \\
\hline M2-B & 147 & $73.5 \pm 0.1$ & $668 \pm 13$ & $191 \pm 4$ & $245 \pm 1$ & $0.1050 \pm 0.0005$ & $9582 \pm 51$ & $9371 \pm 158$ & $251 \pm 1$ & $9311 \pm 158$ \\
\hline M2-C & 162 & $72.5 \pm 0.1$ & $194 \pm 4$ & $792 \pm 16$ & $248 \pm 2$ & $0.1289 \pm 0.0005$ & $11854 \pm 52$ & $11792 \pm 68$ & $256 \pm 2$ & $11732 \pm 68$ \\
\hline M2-D & 197 & $112.3 \pm 0.1$ & $235 \pm 5$ & $1092 \pm 22$ & $225 \pm 2$ & $0.1384 \pm 0.0004$ & $13020 \pm 43$ & $12971 \pm 56$ & $234 \pm 2$ & $12911 \pm 56$ \\
\hline M2-E & 253 & $145.4 \pm 0.1$ & $2525 \pm 51$ & $169 \pm 3$ & $398 \pm 2$ & $0.1779 \pm 0.0005$ & $14747 \pm 45$ & $14389 \pm 257$ & $414 \pm 2$ & $14329 \pm 257$ \\
\hline
\end{tabular}

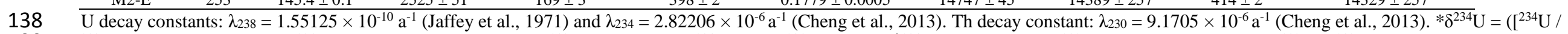

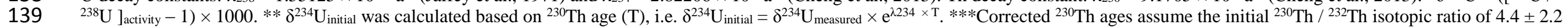

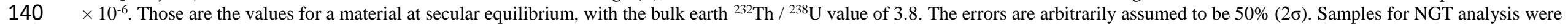

141 taken close to locations where $\mathrm{U} / \mathrm{Th}$ ages were available. 


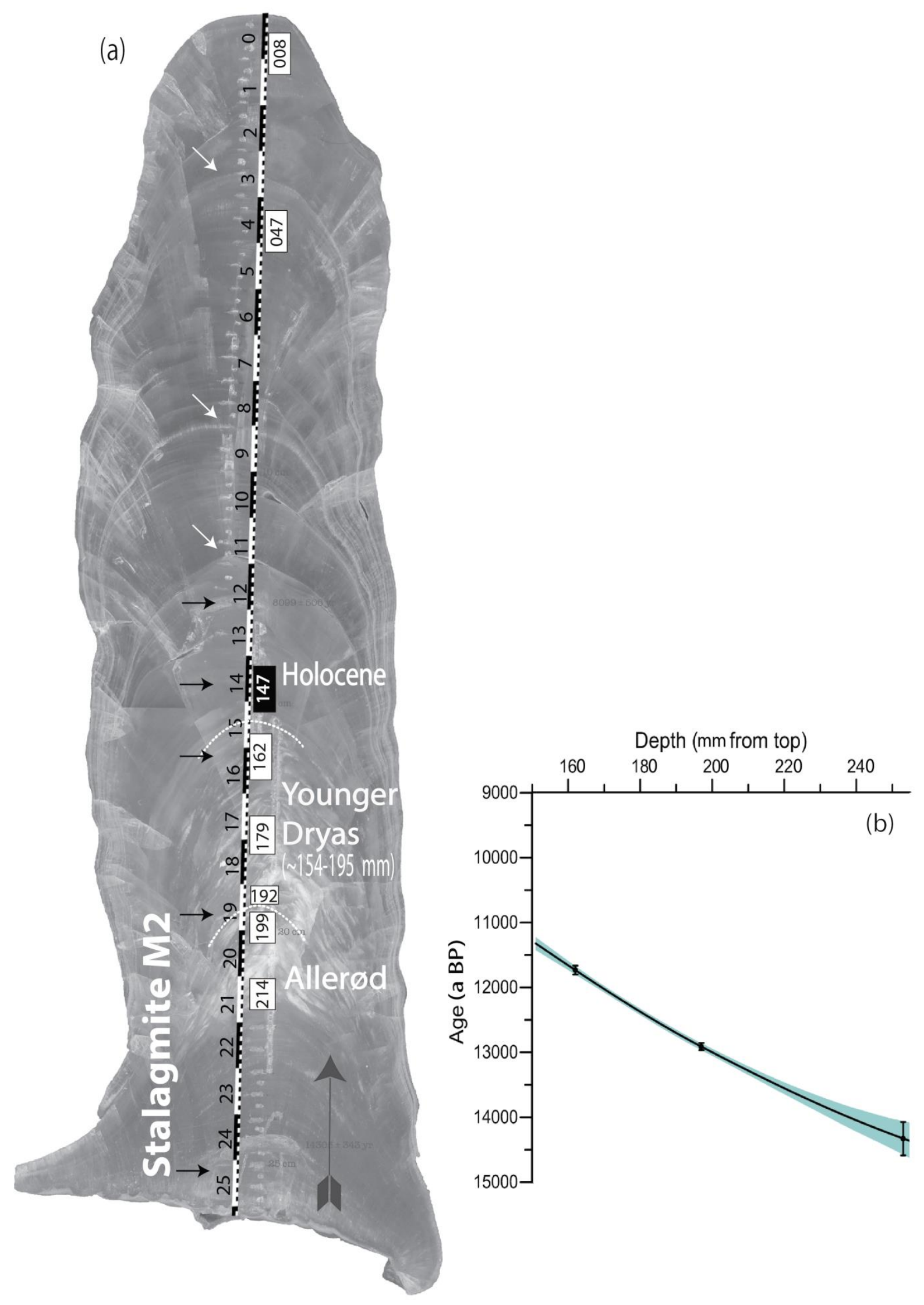

Fig. 2. Sampling of stalagmite M2 (a). Samples were cut out of the stalagmite as 'cubes' with a microsaw and prepared for NGT analysis (see Table 2). Boxes represent samples taken for NGT measurements. Numbers in boxes indicate the mean distance of each sample to the top of the stalagmite in millimeters. White dashed lines mark to the approximate position of the

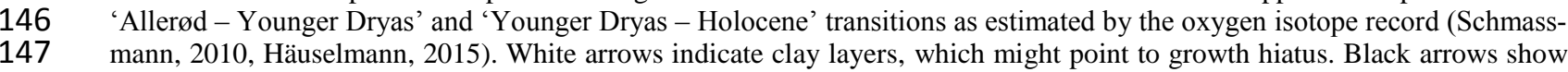


samples dated by U / Th. The gray arrow indicates the growth direction of calcite in the stalagmite M2. The sample at $147 \mathrm{~mm}$ from the top (in the black box) did not contain enough water for a reasonable noble gas analysis and it thus excluded from further discussion. Individual depth-age model of 'older' section of stalagmite M2 (b). The outer shaded zones define the $95 \%$ uncertainties.

\subsection{Sampling procedure for NGT analysis}

In total, eight samples for NGT analysis were cut along the growth axis of stalagmite M2 (Fig. 2). Only one early Holocene sample (at $147 \mathrm{~mm}$ from the top) did not contain enough water for noble gas analysis, therefore, it is excluded from further discussion. Most samples were taken from the transitions of the Late Glacial into the early Holocene, but two samples younger than 8.1 ka BP were also prepared for noble gas analysis.

\subsection{Water and noble gas measurements for NGT determination}

A detailed description of the sample processing using the CVCS system, the gas purification and subsequent noble gas and water content measurements is given in Vogel et al. (2013a) and Scheidegger et al. (2010, 2011). Briefly, each stalagmite sample is crushed in a vacuum to a manually pre-set grain size of $\sim 0.8-1.2 \mathrm{~mm}$ and is then sieved into three grain size fractions of $>0.5 \mathrm{~mm}, 0.5-0.3 \mathrm{~mm}$ and $<0.3$ $\mathrm{mm}$, which are collected in three glass fingers. Of these, solely the coarsest fraction was used for subsequent water and noble gas extraction, because that fraction commonly shows the highest water / air inclusion ratios (Vogel et al. 2013a). Water and noble gases were extracted from the separated fractions by heating the respective glass finger for one hour at $260{ }^{\circ} \mathrm{C}$. The extracted water (and the condensable fluid species) were concentrated cryogenically in a well-defined volume, which was subsequently heated to $\sim 50{ }^{\circ} \mathrm{C}$ to prevent water from condensating and to allow the $\mathrm{H}_{2} \mathrm{O}$ gas pressure to be determined by a high precision manometer (Scheidegger et al., 2010). The mass of the extracted water can be calculated from the water gas pressure in combination with known volume and temperature. In a next step, the extracted noble gases were purified, cryogenically separated into a $\mathrm{He}-\mathrm{Ne}$ and an $\mathrm{Ar}-\mathrm{Kr}-\mathrm{Xe}$ fraction, and quantitatively analyzed in two consecutive steps ( $\mathrm{He}, \mathrm{Ne}$ and $\mathrm{Ar}, \mathrm{Kr}, \mathrm{Xe}$ steps) by static vacuum (noble gas) mass spectrometry (e.g. Beyerle et al., 2000). In contrast to the pure atmospheric noble gases $(\mathrm{Ne}-\mathrm{Xe})$, most of the extracted ${ }^{4} \mathrm{He}$ does not stem from the sample, but is released from the glass into the system when the crushed sample is heated in the glass finger (Vogel et al., 2013a) - therefore, ${ }^{4} \mathrm{He}$ is not discussed. After extraction, the grain separate is heated for a second time ('re-extraction') using 
the same extraction parameters as for the initial extraction. The water and noble gas amounts released

from the according re-extractions were used for 'blank' correction of the respective 'sample' extraction.

${ }^{22} \mathrm{Ne}$ blank correction was large and very variable $(<60 \%)$, whereby the highest values were associated with the two youngest samples M2-047 and -008. Blank corrections of ${ }^{40} \mathrm{Ar},{ }^{86} \mathrm{Kr}$, and ${ }^{136} \mathrm{Xe}$ were smaller and considerably uniform $\left(\sim 5 \%,{ }^{136} \mathrm{Xe}\right.$ in M2-008: 20\%). Blank corrections of the water amounts were $<3 \% .{ }^{22} \mathrm{Ne}$ signals were corrected $(<3 \%)$ for interference of $\mathrm{CO}_{2}{ }^{++}$on mass 22 by monitoring the $\mathrm{CO}_{2}{ }^{+}$ signal and applying an experimentally determined $\mathrm{CO}_{2}{ }^{++} / \mathrm{CO}_{2}{ }^{+}$ratio. The noble gas amounts were determined by normalization to the analyses of calibration gas (known aliquots of air) before or after each sample extraction step (Beyerle et al., 2000). The calibration gas is processed using the same analytical procedure as the sample gas.

\subsection{NGT determination}

Although the CVCS technique reduced the fraction of air-related noble gases of the analyzed stalagmite samples significantly by about 1-2 orders of magnitude (Scheidegger et al. 2010, 2011), the determined noble gas amounts still represent mixtures of noble gases from air and air-saturated water (ASW). To estimate NGTs, the measured amounts of water and noble gases are thus conceptually interpreted as a binary mixture of air released from the air inclusions and of air-saturated water (i.e. noble gases originally dissolved in the water inclusions). The applied mixing model to separate the noble gas concentrations component depends on the following model parameters: the noble gas temperature (NGT, i.e. the temperature at which the fluid inclusion was captured), the amount of air per unit mass of water $(A)$, and the mass of water $(M)$. Such models were originally developed to determine recharge temperatures in (ground)waters from dissolved noble gas concentrations (Mazor , 1972; Kipfer et al., 2002; Jung et al., 2013). For determination of NGTs, a similar regression method is used as is commonly applied in groundwater studies (Aeschbach-Hertig et al., 1999; Ballentine and Hall, 1999) in order to determine the best-fit values of the model variables (NGT, A, and M) through minimizing the sum of the squared error-weighted residuals between the modeled and the measured data $\left(\chi^{2}\right.$-optimization). This method quantifies the model variables NGT, A and M by regression from the measured noble gas concentrations in a statistically sound manner, thus, delivering the paleo-temperature at the time when the calcite was 
deposited. If the assumed model of noble gas partitioning is consistent with the data, the expected $\chi^{2}$ value obtained from the fit is similar to the number of degrees of freedom (DF) of the fit (Press et al., 1986). The number of degrees of freedom of the fit is the difference between the number of measured parameters (noble gas and water amounts) and the number of the fitted model parameters (NGT, A and $\mathrm{M})$.

We note that the commonly used regression methods (Aeschbach-Hertig et al., 1999) implicitly assume that the error of the amount of water of a given sample is negligibly small and, hence, does not affect the calculation of the total error of the noble gas concentrations. This is a valid assumption for water samples larger than $1 \mathrm{~g}$ as it is the case for (ground) water in the classical approach. In the case of stalagmites, however, the error of the minute amount of water extracted from a calcite sample contributes significantly to the total error of the determined atmospheric noble gas concentrations. Thus, ignoring the error of the extracted water mass principally undermines the basic assumption of statistically uncorrelated errors which is fundamental for any $\chi^{2}$ based regression method. To avoid the correlation of errors, we did not fit noble gas concentrations, but treated noble gas abundances and water amounts determined in each sample as independent parameters to be fitted. To this end, we developed a new, more flexible regression tool, which is also based on the $\chi^{2}$ minimization technique (please see more details: http://brennmat.github.io/noblefit/). This new tool allows a statistically sound assessment of the quality of the fit based on the resulting $\chi^{2}$-value also in the case of stalagmite samples as the error for the water mass determination is explicitly accounted for. Like other codes (Aeschbach-Hertig et al., 1999), the new tool also provides statistically sound estimates of the uncertainties of the fitted parameters by propagating the analytical errors of the noble gas and water amounts.

\section{Results}

\subsection{Elemental ratios}

Before estimating NGTs to study the temperature evolution of the Milandre site during the last $15 \mathrm{ka}$, we check if the measured noble gas amounts (Table 2) can conceptually be described by binary mixing model of unfractionated air and ASW. In a three-element plot (Fig. 3), any such mixture falls on a straight line connecting the two endmember compositions. Fitting algorithms yield statistically robust 
Table 2

234 Measured water and noble gas amounts in stalagmite M2 from the Milandre cave.

\begin{tabular}{|c|c|c|c|c|c|}
\hline Sample & $\begin{array}{l}\text { Water amounts } \\
\left.\qquad \times 10^{-5} \mathrm{~g}\right]\end{array}$ & $\begin{array}{c}\mathrm{Ne} \\
{\left[\times 10^{-12}\right]}\end{array}$ & $\begin{array}{c}\mathrm{Ar} \\
{\left[\times 10^{-10}\right]}\end{array}$ & $\begin{array}{c}\mathrm{Kr} \\
{\left[\times 10^{-12}\right]}\end{array}$ & $\begin{array}{c}\mathrm{Xe} \\
{\left[\times 10^{-12}\right]}\end{array}$ \\
\hline M2-214 & $20.0 \pm 0.8$ & $479 \pm 8$ & $3318 \pm 47$ & $49.3 \pm 0.6$ & $5.8 \pm 0.3$ \\
\hline M2-199 & $14.4 \pm 1.1$ & $226 \pm 5$ & $1704 \pm 24$ & $27 \pm 0.3$ & $3.5 \pm 0.1$ \\
\hline M2-192 & $11.1 \pm 0.8$ & $203 \pm 5$ & $1596 \pm 23$ & $24.5 \pm 0.3$ & $3 \pm 0.1$ \\
\hline M2-179 & $7.2 \pm 0.9$ & $66 \pm 5$ & $719 \pm 10$ & $13.1 \pm 0.2$ & $1.8 \pm 0.2$ \\
\hline M2-162 & $8.9 \pm 0.8$ & $73 \pm 3$ & $643 \pm 9$ & $11.8 \pm 0.6$ & $1.6 \pm 0.1$ \\
\hline M2-047 & $6.5 \pm 0.6$ & $31 \pm 2$ & $285 \pm 4$ & $4.8 \pm 0.1$ & $0.9 \pm 0.04$ \\
\hline M2-008 & $3.3 \pm 0.7$ & $10 \pm 2$ & $94 \pm 1$ & $1.9 \pm 0.04$ & $0.4 \pm 0.02$ \\
\hline
\end{tabular}

Noble gas amounts are in $\mathrm{cm}^{3} \mathrm{STP}\left(1 \mathrm{~mole}=22414 \mathrm{~cm}^{3} \mathrm{STP}\right)$. Uncertainties of water and gas amounts are given at the $1 \sigma$ level.

Uncertainties of the water amounts include the error of the manometric pressure reading to determine the water vapor pressure, the error of the temperature of the water basin keeping the calibration volume at a constant and uniform temperature, and the error of the calibration volume for the pressure determination to which the noble gases and water were expanded. The overall uncertainty also accounts for the systematic error associated with the correction for a small fraction of water that interacts with the inner walls of the extraction line (see Vogel et al., 2013a). Uncertainties of noble gas amounts include errors associated with ion counting statistics, interference and blank corrections, and errors related to absolute noble gas calibration (for the details see Beyerle et al., 2000; Vogel et al., 2013a). Ne, Ar, $\mathrm{Kr}$, and $\mathrm{Xe}$ amounts were calculated from the measured ${ }^{22} \mathrm{Ne}$, ${ }^{40} \mathrm{Ar},{ }^{86} \mathrm{Kr}$, and ${ }^{136} \mathrm{Xe}$ abundances using the respective atmospheric isotopic compositions (Kipfer et al., 2002, and references therein).

In all three panels of Fig. 3, the composition of sample M2-162 falls on the mixing area within $1 \sigma$

uncertainties, indicating four atmospheric noble gases are consistent with the interpretation of binary

mixtures of air and ASW. Thus, all atmospheric noble gas concentrations can be consistently translated into common NGT values (Table 3).

The composition of all other samples show offsets from the mixing areas in at least one of the 3 elematch with the expected mixing area of ASW and air is found for samples M2-214, -199, and -192 for

$\mathrm{Ne} / \mathrm{Kr}$ and $\mathrm{Xe} / \mathrm{Kr}$ ratios (Fig. 3b). In fact, $\mathrm{Ne}, \mathrm{Kr}$, and $\mathrm{Xe}$ can conceptually much better be interpreted as binary mixing of ASW and air than Ar, Kr, Xe compositions. These observations point to a singular excess of Ar in these samples. We note that Ar enrichment relative to the other atmospheric noble gases is only observed during the first extraction ('sample', see section 2.3.) whereas the re-extraction is not affected ('blank'). Because the re-extractions, which are used for blank correction, hardly contain any water or any other extractable fluid, thus Ar excess is not 'produced'. As a result, the blank corrections 
it is thus concluded that the observed Ar excess in not related to any kind of external process (e.g. leak),

262

but is due to an internal process which is only operational if extracted gases and water interact with the interior surface of the extraction line ('memory effect'). Most likely - we hypothesize - Ar is liberated from the interior surface of the extraction line in a kind exchange reaction. The extracted water and gases of the first extraction adsorb to metal surfaces and displace the Ar previously sitting at the same position (e.g. due to air calibration or venting of the system, etc.) as the reactive species bind significantly stronger than the non-reactive Ar.

Notably, samples with higher water yields (Table 2) seem to be subject to higher Ar enrichment than samples with less water - an observation which adds some support to the idea that the observed Ar enrichment might indeed be result of an internal exchange process. Although caution needs to be exercised in drawing final conclusions we are tempted to identify the Ar source in some of the used getter material as these alloys were produced under a protecting Ar atmosphere. In conclusion, Ar in samples M2-214, -199, and -192 originates from three and not from two different components (Air, ASW and from the internal extraction processes). Therefore, Ar for these samples cannot be interpreted in terms of a binary mixture of air and ASW. Thus, NGTs in the samples M2-214, -199, and -192 can only be determined from $\mathrm{Ne}, \mathrm{Kr}$, and $\mathrm{Xe}$ concentrations.

Sample M2-179 seems to be depleted in Ne (Fig. 3c) whereas Ar, Kr, and Xe concentrations are the results of binary mixing of ASW and air (Fig. 3a). A potential reason for the observed Ne-deficit is an inappropriately large blank correction (30\%). Heating experiments using empty glass fingers show that the glass does not only become permeable for He (Vogel et al., 2013a), but also for Ne, but to a much smaller extent. Thus, blank corrections especially for samples with very low noble gas abundance (M2179) might become inadequate. However, Ar, Kr, and Xe appear to be unaffected (Fig. 3a and caption of Table 3) and thus these concentrations can be converted into NGT.

The two youngest samples M2-047 and M2-008 show strongly fractionated element patterns in the Ar / $\mathrm{Kr}$ vs. $\mathrm{Xe} / \mathrm{Kr}$ and the Ne / Kr vs. Xe / Kr plots (Figs. 3a and 3b). These shifts are most probably due to $\mathrm{Xe}$ enrichment in these samples as $\mathrm{Ne}, \mathrm{Ar}$, and $\mathrm{Kr}$ can reasonably be understood as binary mixtures of 

discussed in detail in section 3.2.2.
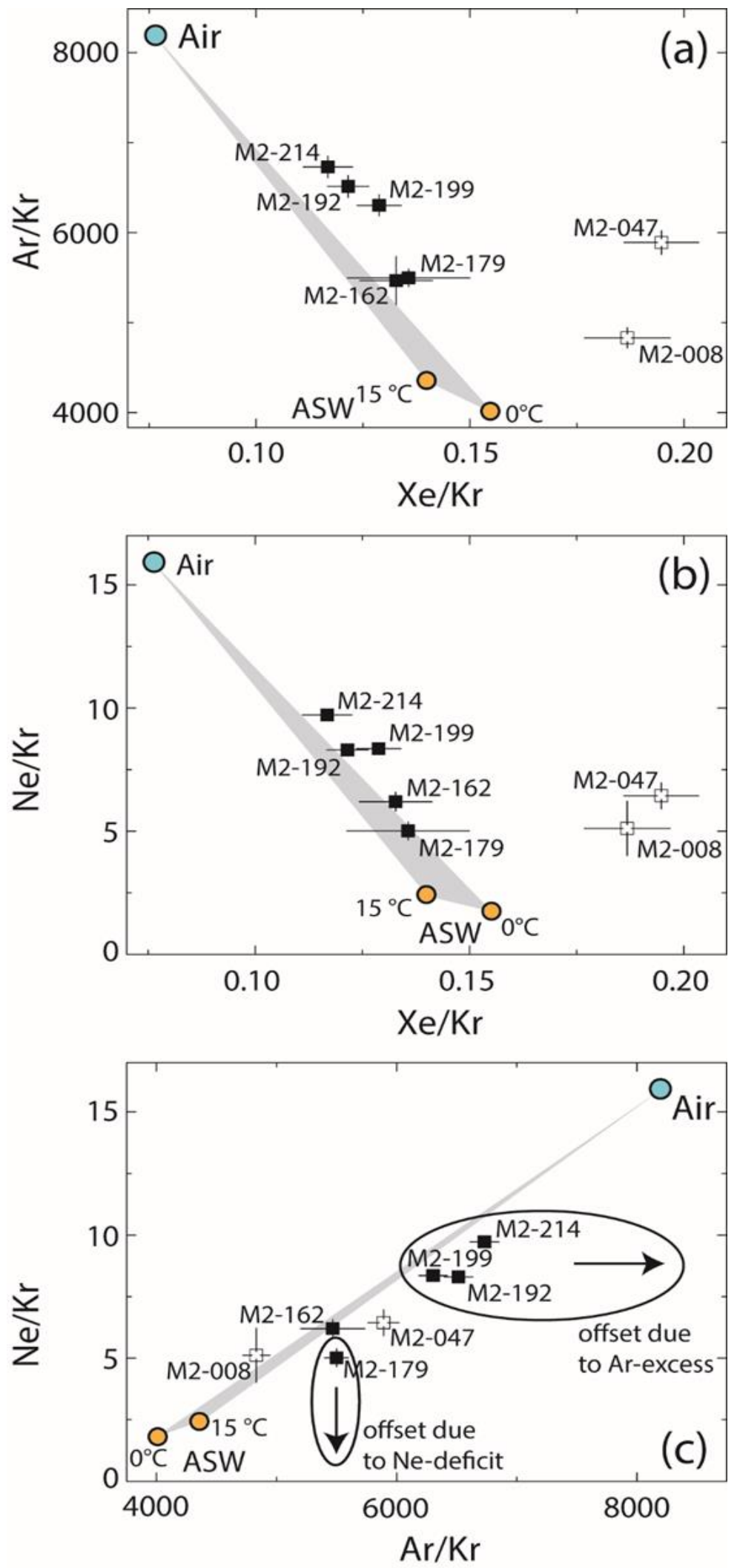

Fig. 3. Three element plots $\mathrm{Ar} / \mathrm{Kr}$ vs. $\mathrm{Xe} / \mathrm{Kr}$ (a), $\mathrm{Ne} / \mathrm{Kr}$ vs. $\mathrm{Xe} / \mathrm{Kr}$ (b), and $\mathrm{Ne} / \mathrm{Kr}$ vs. $\mathrm{Ar} / \mathrm{Kr}$ (c). Errors are reported at $1 \sigma$ level. It is also shown the light gray mixing areas between the endmember compositions of air and air-saturated water (ASW). The salinity of drip water entering the cave is typically very low and, thus, it has a very minor effect on noble gas 
solubilities. Therefore, ASW compositions are calculated for freshwater with temperatures between 0 and $15{ }^{\circ} \mathrm{C}$ taking into account the elevation of Milandre Cave of $400 \mathrm{~m}$ a.s.l. and using suitable noble gas solubility data (Kipfer et al., 2002 and references therein). The empty squares show the recently precipitated stalagmite ('young') samples which cannot be interpreted in paleo-temperature terms.

\subsection{Stalagmite M2 noble gas temperatures}

We used two different sets of atmospheric noble gases to evaluate NGTs (Table 3): NGT 1 estimated from the water amounts and the abundance of all four atmospheric noble gases ( $\mathrm{Ne}, \mathrm{Ar}, \mathrm{Kr}$, and $\mathrm{Xe})$ and $\mathrm{NGT}_{2}$ from the water amounts and those three atmospheric noble gases (e.g. only using $\mathrm{Ne}, \mathrm{Kr}$, and $\mathrm{Xe}$ ) of the particular samples which are in good agreement with the model of a binary mixture of air and ASW. Except for the two youngest samples (M2-008 and M2-047), the $\mathrm{NGT}_{1}$ and $\mathrm{NGT}_{2}$ agree within their $1 \sigma$ uncertainties. However, as expected, the $\chi^{2}$-values of the $\mathrm{NGT}_{2}$ fits (e.g. only using $\mathrm{Ne}, \mathrm{Kr}, \mathrm{Xe}$ ) are much closer to the respective values of DF than those associated with $\mathrm{NGT}_{1}$ (i.e. fitting all atmospheric noble gases $\mathrm{Ne}, \mathrm{Ar}, \mathrm{Kr}$ and $\mathrm{Xe}$ ). For sample M2-162 $\mathrm{Ne}, \mathrm{Ar}, \mathrm{Kr}$ and $\mathrm{Xe}$ can be interpreted as binary mixtures of air and $\mathrm{ASW}$, thus $\mathrm{NGT}_{1}$ and $\mathrm{NGT}_{2}$ are identical and $\chi^{2}$ values in either case match the number of degree of freedom.

\subsubsection{Allerød and Younger Dryas samples}

At the end of the Allerød (samples M2-214, and -199), the reconstructed annual mean temperature in Milandre Cave are $1.8 \pm 1.5$ and $2.6 \pm 2.2^{\circ} \mathrm{C}$. At the onset of the Younger Dryas the cave temperature dropped down to a temperature close to zero degree (M2-192 and M2-179). Cave temperatures below 0 ${ }^{\circ} \mathrm{C}$ are not captured by stalagmites due to the possible lack of liquid water and the resulting reduction of stalagmite growth rate. A cave / soil temperature of $0{ }^{\circ} \mathrm{C}$ is regarded as maximum temperature estimate. NGTs increase considerably towards the end of the Younger Dryas, reaching $6.3 \pm 2.6^{\circ} \mathrm{C}(\mathrm{M} 2-162)$. At the end of the Younger Dryas, noble gas data indicates an annual mean temperature at the Milandre Cave of $6.3 \pm 2.6^{\circ} \mathrm{C}$. The given error of this temperature accounts for the age uncertainty as a single calcite samples $\left(1 \times 1 \times 1 \mathrm{~cm}^{3}\right)$ integrates over a considerable time interval. Taking into account the large error (e.g. related to sample preparation and dating), to our point of view the temperature of this sample most likely marks the transition into the Holocene. This interpretation is in good agreement with increasing $\delta^{18} \mathrm{O}$ at the early Holocene in Fig. 4. As noted earlier, a NGT could not be determined for the early Holocene as these samples did not contain enough extractable water. 


\subsubsection{Late Holocene samples (M2-047 and M2-008)}

323

$\mathrm{NGT}_{2}$ of the two youngest samples M2-047 and M2-008 are significantly higher than $20^{\circ} \mathrm{C}$. Such high temperatures at the cave site are impossible because the recent annual mean temperature in Milandre Cave does not exceed $10{ }^{\circ} \mathrm{C}$ and given the recent climate evolution it appears reasonable to assume that past cave temperatures were never higher during the past few thousand years. Therefore, we conclude that these recently precipitated stalagmite ('young') samples (i.e. being close to growing zone) must have been affected by a process that depleted the atmospheric noble gas concentrations and fractionated the according elemental ratios in the water-filled inclusions after the stalagmite M2 was cut and prepared for noble gas analysis in the laboratory. The recently precipitated stalagmite ('young') samples M2-047 and M2-008 show significantly lower noble gas and water abundances in comparison with the old part of the stalagmite that crystallized a long time age (see Table 2). Further, the low water and noble gas amounts and the fractionated noble gas ratios point towards some gas loss which depleted noble gases concentrations in the water filled inclusions whereby $\mathrm{Ne}, \mathrm{Ar}$ and $\mathrm{Kr}$ were more affected than $\mathrm{Xe}$ (Table 2, Figs. 3a and 3b). The observed elemental fractionation indicates that the assumed gas loss might be controlled by solubility or molecular diffusion which are known in aquatic systems to deplete $\mathrm{Ne}, \mathrm{Ar}$ and $\mathrm{Kr}$ with regard to $\mathrm{Xe}$ as $\mathrm{Xe}$ has the lowest Henry coefficient (i.e. is most soluble) and smallest diffusion coefficient among noble gases in water (Jähne et al., 1987; Kipfer et al., 2002; Tyroller et al., 2016; de Magalhães et al., 2017).

Similar noble gas depletion and fractionation were also reported from a comprehensive study comparing different methods to reconstruct past temperatures from stalagmites from Borneo (Meckler et al., 2015). This study also reported gas loss in the recently precipitated stalagmite samples (i.e. showing unreasonably high NGTs) but also showed that some of the emerging novel methods to retrieve environmental information for stalagmites (e.g. homogeneous temperatures of fluid inclusion) have limitations if being applied to recently precipitated calcites. In contrast, the 'old' samples were found to be unaffected and the respective noble gas concentrations were successfully converted into more meaningful cave temperatures (Meckler et al., 2015).

According to our experimental CVCS protocols to process stalagmite samples, prior to crushing stalagmite samples are stored in the CVCS chamber for about 1 to 2 days at around $40{ }^{\circ} \mathrm{C}$ when the glass 
fingers were heated up to $350{ }^{\circ} \mathrm{C}$ to reduce operational blanks during the later thermal gas extraction.

351

The 'clean' glass fingers were used later for thermal gas extraction. After crushing to the pre-set grain size, the crushed and separated stalagmite samples are stored in their respective glass fingers at room temperature. During that time, they are pumped for several hours to remove the noble gases from the air-filled inclusions which were preferentially cracked open by the crushing procedure (for details, see Vogel et al., 2013a). In either case (e.g. during storage as uncrushed pre-heated samples or during storage and pumping of the crushed samples), stalagmite samples can be subject to gas and water loss as they are exposed to lower pressure and higher temperatures (e.g. room temperature or higher) than in the cave. Based on our still limited dataset, we postulate that the currently available experimental protocols yield systematically too low water and noble gas abundances for very recently precipitated stalagmite ('young') samples as such samples seem to be susceptible to gas loss under vacuum conditions. In support of our hypothesis, we refer to Thompson (1973) who also reported significant water loss (< $20 \%$ ) when recently precipitated stalagmite sample was heated to $60^{\circ} \mathrm{C}$.

As $\mathrm{Xe}$, due to its low diffusivity and large solubility, is less subject to gas loss, we tried to use the Xe abundances to roughly estimate NGT for the recently precipitated stalagmite samples. Assuming that all remaining Xe in M2-047 and M2-008 originated from the ASW component, we derived temperatures of around $6{ }^{\circ} \mathrm{C}$ and $14{ }^{\circ} \mathrm{C}$, respectively. Although a fraction of the Ne has obviously been lost, Ne might still be used for a tentative air correction for Xe. Doing so, a NGT of $8.7 \pm 2.7^{\circ} \mathrm{C}$ is determined for M2047 and $15.6 \pm 6.7^{\circ} \mathrm{C}$ for M2-008. At least in case for M2-047, the roughly scaled NGT agrees reasonably well with the modern temperature of the Milandre cave. The true NGT originally captured by the recently precipitated stalagmite samples might well have been lower (Xe loss due to baking, see above), but certainly cannot have been higher than these values (Table 3). 
372 Table 3

373 NGTs of Stalagmite M2.

Fits with complete set of tracers

$(\mathrm{Ne}, \mathrm{Ar}, \mathrm{Kr}, \mathrm{Xe})$

\begin{tabular}{|c|c|c|c|c|c|c|c|c|c|c|c|c|}
\hline & Sample & Age (time interval ka) & $\begin{array}{c}\mathrm{M} \\
{[\mathrm{mg}]}\end{array}$ & $\mathrm{NGT}_{1}\left[{ }^{\circ} \mathrm{C}\right]$ & $\begin{array}{c}\mathrm{A}_{1} \\
{\left[\mathrm{~cm}^{3} \mathrm{STP} / \mathrm{g}\right]}\end{array}$ & $\chi_{1}^{2}$ & $\mathrm{ADF}_{1}$ & $\mathrm{NGT}_{2}\left[{ }^{\circ} \mathrm{C}\right]$ & $\begin{array}{c}\mathrm{A}_{2} \\
{\left[\mathrm{~cm}^{3} \mathrm{STP} / \mathrm{g}\right]}\end{array}$ & $\chi_{2}^{2}$ & $\# \mathrm{DF}_{2}$ & $\begin{array}{l}\text { Tracer set used for } \\
\text { fitting }\end{array}$ \\
\hline \multirow{5}{*}{$\begin{array}{c}\text { Old } \\
\text { samples }\end{array}$} & M2-214 & $13.4(13.2-13.5)$ & $0.199 \pm 0.008$ & $2.2 \pm 1.5$ & $0.123 \pm 0.006$ & 11.7 & 2 & $1.8 \pm 1.5$ & $0.121 \pm 0.006$ & 1.2 & 1 & $\mathrm{Ne}, \mathrm{Kr}, \mathrm{Xe}$ \\
\hline & M2-199 & $12.95(12.8-13)$ & $0.139 \pm 0.011$ & $3.7 \pm 2.3$ & $0.077 \pm 0.007$ & 13.3 & 2 & $2.6 \pm 2.2$ & $0.077 \pm 0.007$ & 4.6 & 1 & $\mathrm{Ne}, \mathrm{Kr}, \mathrm{Xe}$ \\
\hline & M2-192 & $12.76(12.7-12.8)$ & $0.113 \pm 0.008$ & $1.2 \pm 2$ & $0.093 \pm 0.007$ & 23.5 & 2 & $0_{(-)}^{+} 2^{*}$ & $0.087 \pm 0.007$ & 0.3 & 1 & $\mathrm{Ne}, \mathrm{Kr}, \mathrm{Xe}$ \\
\hline & M2-179 & $12.3(12.2-12.5)$ & $0.072 \pm 0.009$ & $0 \pm 3$ & $0.045 \pm 0.007$ & 16.1 & 2 & $0_{(-)}^{+} 3.2^{*}$ & $0.057 \pm 0.009$ & 0.4 & 1 & $\mathrm{Ar}, \mathrm{Kr}, \mathrm{Xe}$ \\
\hline & M2-162 & $11.7(11.5-11.9)$ & $0.089 \pm 0.008$ & $6.3 \pm 2.6$ & $0.034 \pm 0.004$ & 0.4 & 2 & $6.3 \pm 2.6$ & $0.034 \pm 0.004$ & 0.4 & 2 & $\mathrm{Ne}, \mathrm{Ar}, \mathrm{Kr}, \mathrm{Xe}$ \\
\hline Young & M2-047 & $2.94(2.6-3.2)$ & $0.066 \pm 0.006$ & $(20.9 \pm 3.3)$ & $0.019 \pm 0.003$ & 84.3 & 2 & $(31 \pm 3.8)$ & $0.020 \pm 0.003$ & 2.6 & 1 & $\mathrm{Ne}, \mathrm{Ar}, \mathrm{Kr}$ \\
\hline Samples & M2-008 & $0.34(-0.02-0.71)$ & $0.031 \pm 0.007$ & $(-4.5 \pm 9.4)$ & $0.018 \pm 0.013$ & 28.0 & 2 & $(25.8 \pm 8.1)$ & $0.004 \pm 0.004$ & 1.5 & 1 & $\mathrm{Ne}, \mathrm{Ar}, \mathrm{Kr}$ \\
\hline
\end{tabular}

$\mathrm{NGT}_{1}, \mathrm{NGT}_{2}$ and amounts of air per unit mass of water $\left(\mathrm{A}_{1}, \mathrm{~A}_{2}\right)$ determined for stalagmite M2. NGT $1, \mathrm{~A}_{1}, \chi_{1}^{2}$, and \#DF $\mathrm{D}_{1}$ were determined using the complete set of measured noble gases Ne, Ar, Kr, and Xe abundances. $\mathrm{NGT}_{2}, \mathrm{~A}_{2}, \chi_{2}^{2}$ and $\mathrm{HDF}_{2}$ were determined using a reduced set of noble gases, which agree best with the model assumption of a binary mixture of air and ASW. M: fitted water mass. The regression method and fit statistics $\left(\chi^{2}, \# D F\right)$ are explained in section 2.4. All uncertainties are given at $1 \sigma$ level. Ages represent mean ages of the sampled interval based on the age models of each sample. * A calculated temperature below the freezing point of water is the result of the mathematical error propagation and has no paleo-climatic meaning. ${ }^{\text {a }}$ For sample M2-162 Ne, Ar, Kr and Xe can be interpreted as binary mixtures of air and ASW, thus NGT 1 and NGT $_{2}$ are identical and $\chi^{2}$ values, in either case match the number of degree of freedom. ( ): Unrealistic temperature estimations due to different structure compared to other samples. Therefore, no meaningful temperature could be determined for recently precipitated stalagmite samples. 


\section{Discussion}

381

382

383

384

385

386

387

388

389

390

391

392

393

394

395

396

397

398

399

400

\subsection{Independent paleo-temperature information for the Milandre Cave area}

In the following section, we compare our stalagmite-based NGTs with other temperature reconstructions from four locations in Northwestern Switzerland: Gerzensee, 603 m a.s.l. (Lotter et al., 2000), Hinterburgsee, $1515 \mathrm{~m}$ a.s.l. (Heiri et al., 2003), Le Locle, $915 \mathrm{~m}$ a.s.l. (Magny et al., 2001), and Eastern France: Lac Lautrey, $788 \mathrm{~m}$ a.s.l. (Heiri and Millet, 2005). These locations are within a radius of $\sim 120$ km from the Milandre Cave (Fig. 1). However, these paleo-temperature records are based on pollen, cladoceran, and chironomid assemblages and, therefore, are seasonally biased towards summer temperatures (June, July, and August).

Table 4 summarizes available paleo-temperature information from four close-by locations in Northwestern Switzerland and Eastern France that have different altitudes. We note that these estimates are based on different methods that strictly speaking reconstructed different temperatures (e.g. annual mean temperature (Magny et al., 2001), summer temperature (Lotter et al., 2000), and July temperature (Heiri et al., 2003; Heiri and Milet, 2005, see Table 4 for details).

Table 4

$\underline{\text { Independent paleo-temperature information from four locations in Northwestern Switzerland and Eastern France }}$

\begin{tabular}{ccccc}
\hline \multirow{2}{*}{ Location } & Le Locle & Gerzensee & Hinterburgsee & Lac Lautrey \\
& $915 \mathrm{~m}$ & $603 \mathrm{~m}$ & $1515 \mathrm{~m}$ & $788 \mathrm{~m}$ \\
\hline \multirow{2}{*}{ Intervals } & Pollen & Pollen \& Cladoceran & Chironomid & Chironomid \\
\cline { 2 - 5 } & Annual mean temperature & Summer temperature & July temperature & July temperature \\
\hline End of Bølling & n.d. & n.d. & n.d. & 16 \\
Allerød & n.d. & $11-13$ & n.d. & $16.5-17$ \\
Allerød -Younger Dryas & $3-5.5$ & $9-10$ & n.d. & 15 \\
Younger Dryas - Holocene & $3.5-6.5$ & $11.5-12$ & $10.4-10.9$ & 14 \\
Early - Middle Holocene & $8-10$ & $14-15$ & $11.9-12.8$ & 16.5 \\
Late Holocene & n.d. & n.d. & $11.5-12$ & n.d.
\end{tabular}

Temperatures in ${ }^{\circ} \mathrm{C}$, altitude in meters a.s.l.. The paleo-temperature information is derived from pollen (Lotter et al., 2000; Magny et al., 2001), chironomid (Heiri et al., 2003; Heiri and Millet et al., 2005) and cladoceran (Lotter et al., 2000) assemblages from sediment cores of lakes. Investigated sites are located within a $120 \mathrm{~km}$ radius from the Milandre cave (n.d. $=$ no data).

\subsection{Comparison of NGTs with published paleo-temperature information for the Milandre Cave}

In order to compare these various temperature reconstructions with each other and with our stalagmite

M2 NGTs, all records need to be rescaled to the elevation of the Milandre Cave (400 $\mathrm{m}$ a.s.1.). This 
temperature) of each site according to the respective present-day atmospheric laps rate (summer: $0.6{ }^{\circ} \mathrm{C}$ / 100 m, e.g. Livingstone et al., 1999, and the annual mean laps rate: $0.5^{\circ} \mathrm{C} / 100 \mathrm{~m}$, e.g. Magny et al., 2001). We also account for the slight difference between cave temperature and the temperature outside the cave at the Milandre site $\left(0.5^{\circ} \mathrm{C}\right.$, see below). Next and most importantly, the scaled summer and July temperatures have to be converted to annual mean temperatures; i.e. to those temperatures recorded by the noble gases in stalagmites. To carry out this transformation, we compared long term instrumental temperature records from Zürich (Switzerland: 1935-1993), Basel (Switzerland: 1849-1998), and Fahy (Switzerland: 1985-2011), which show a stable temperature difference $(\Delta T)$ of about $8{ }^{\circ} \mathrm{C}$ between summer and annual mean temperatures, and a difference of $9{ }^{\circ} \mathrm{C}$ between the July and annual mean temperatures. However, the climate in Middle Europe at the end of the last glacial is generally assumed to have been more continental than today, i.e. being characterized by a larger annual temperature amplitude (Wick, 2000). Therefore, present day $\Delta T s$ were also analyzed for locations which either show summer temperatures similar to the ones most probably prevailing at the Milandre site during the Allerød Younger Dryas - Holocene (e.g. Helsinki, Stockholm, Uppsala, Oslo, Umea, Östersund, Trondheim, Selbu, Oulu, Kemi), or which lie at a similar geographical latitude as Milandre, but in a more continental climate setting (Vienna, Budapest, Bishkek, Astana). Resulting $\Delta T s$ are found to be indeed higher ( 11 ${ }^{\circ} \mathrm{C}$ difference between summer and annual mean temperature, and $12{ }^{\circ} \mathrm{C}$ between July and annual mean temperature). We therefore decide to use the mean of the two $\Delta T$ estimates for converting summer / July temperatures to annual mean temperatures (summer temperature $\rightarrow$ annual mean temperature: $9.5^{\circ} \mathrm{C}$, July temperature $\rightarrow$ annual mean temperature: $10.5^{\circ} \mathrm{C}$ ). These mean $\Delta T$ values are used to convert the Late Glacial and early Holocene samples ('continental climate'), but for younger samples the present day temperature lag is applied ('recent climate'). We are aware that the seasonal variation can affect the conversion from summer temperature to mean annual temperature and a long summer season can dominate over the winter season and vice versa. However, there is no data available to allow us to estimate this effect. Further, our calcite samples have a length of $\sim 10 \mathrm{~mm}$ and integrate climatic evolution over rather long time periods (e.g. 1 ka) and, thus, cannot catch short-term variations. Therefore, the NGTs capture only temporarily integrated temperature signals. 

to the conversion of July / summer temperatures to annual mean temperatures. We explicitly note that the assigned uncertainty is not related to the original temperature estimations - in fact most studies do not quote any errors - but it is related to the conversion of the determined temperature (e.g. summer or July temperature) to the annual mean temperature.

Fig. 4 summarizes our stalagmite-derived NGTs and the converted annual mean temperatures for Milandre Cave inferred from the literature temperatures being scaled to annual mean temperature as described.

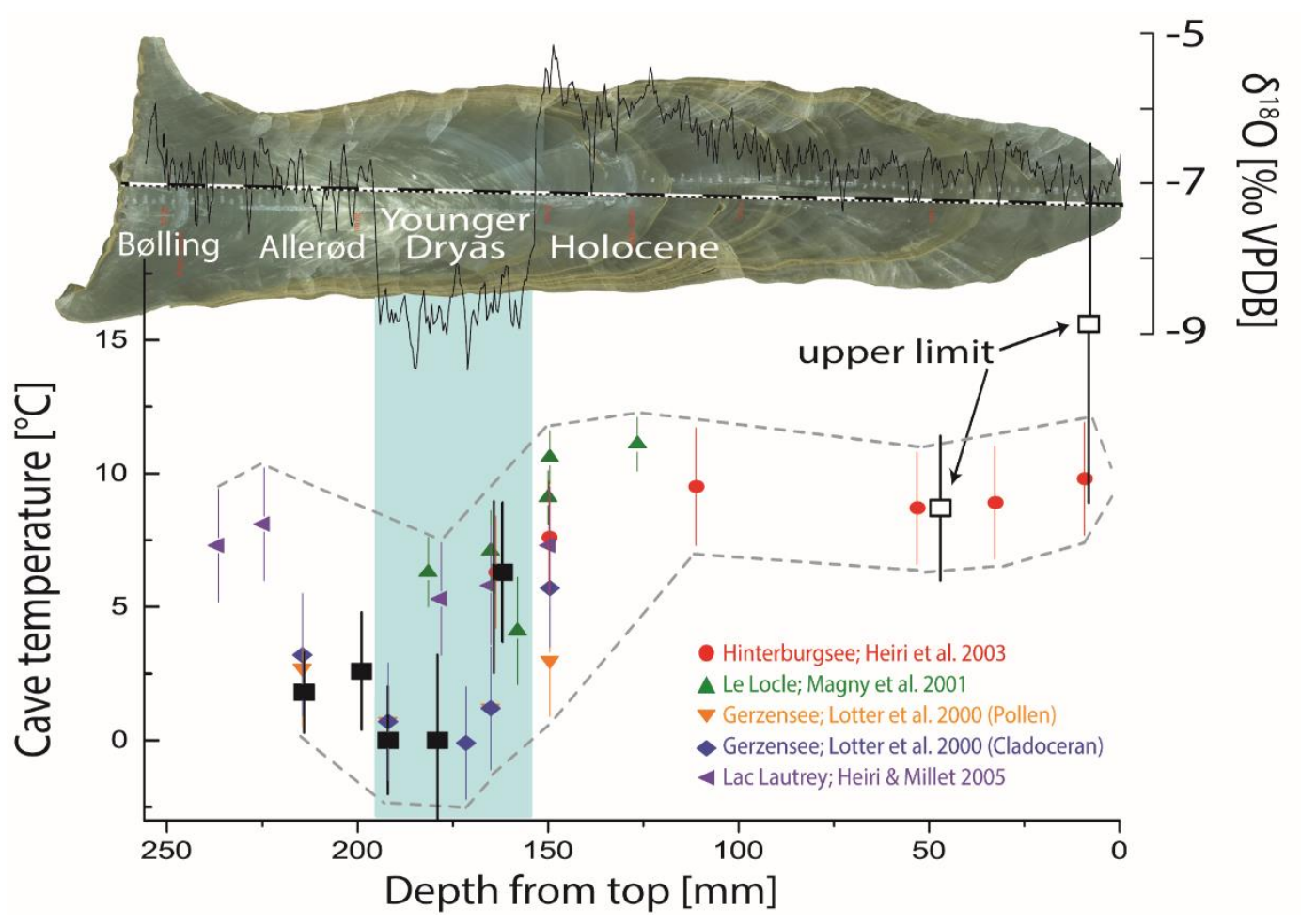

Fig. 4. Reconstructed NGTs (solid and open black squares) in comparison with temperature reconstructions from other studies represent the combined uncertainties from the small errors (if available) in the original publication and, except for the annual mean temperatures reported by Magny et al. (2001), from the large uncertainties introduced by scaling of the summer / July temperatures to annual mean temperature. Dashed lines delineate the upper and lower temperature limits derived from literature values. The Younger Dryas is visualized by the blue area and is also clearly visible in the sharp negative excursion of $\delta^{18} \mathrm{O}$ in the M2 stalagmite (Schmassmann, 2010; Häuselmann, 2015). The magnitude of the variation of the $\delta^{18} \mathrm{O}$ record is in agreement with data from Lake Ammersee (south Germany, von Grafenstein et al., 1998). Open squares represent best NGT guess estimated from Ne and Xe only (see text for further information).

The data in Fig. 4 makes the case that all determined NGTs agree with the range of the converted annual mean temperatures derived from pollen, cladoceran, and from chironomid assemblages in lake sediments. The Lac Lautrey records (Heiri and Millet, 2005) of the chironomid-based temperature at the end of Bølling show high temperatures which cannot be compared to our NGTs reconstruction because only 
the earlier part of the Younger Dryas annual mean temperatures at the lower margin of the converted published temperature estimates, i.e. $1.8 \pm 1.5$ to $2.6 \pm 2.2{ }^{\circ} \mathrm{C}$ during the Allerød and $0 \stackrel{(-)}{+} 2{ }^{\circ} \mathrm{C}$ at the onset of the Younger Dryas. While the temperature difference at the transition Allerød - Younger Dryas corroborates previous results, the absolute temperatures reconstructed from noble gases are systematically lower than annual mean temperatures derived from pollen data from Le Locle (Magny et al., 2001). However, both pollen and cladoceran assemblages from Gerzensee (Lotter et al., 2000) indicate the same low annual mean temperatures as our NGTs (for the Allerød - Younger Dryas transition). At the end of the Younger Dryas, noble gas data indicates an annual mean temperature at the Milandre Cave of $6.3 \pm 2.6{ }^{\circ} \mathrm{C}$, identical to temperature estimates derived from Le Locle, Lac Lautrey, and Hinterburgsee data (Magny et al., 2001; Heiri et al., 2003; Heiri and Millet, 2005). The respective temperature increase reconstructed from the sediments of Gerzensee is observed somewhat later, just after the onset of the Holocene. The relatively warm early Holocene temperatures, as seen in the Le Locle record (Magny et al., 2001), stabilized through most of the Holocene at somewhat lower temperatures of around $8{ }^{\circ} \mathrm{C}$ (with some brief excursions toward lower temperatures, e.g. Heiri et al., 2003). This average Holocene temperature is well reproduced by our maximum temperature estimate from sample M2-047 (8.7 $\pm 2.7^{\circ} \mathrm{C}$ at around $2.9 \mathrm{ka} \mathrm{BP}$ ). This agreement suggests that $\mathrm{Xe}$ was completely retained in this sample despite considerable loss of the lighter noble gases. In contrast, the maximum temperature estimate for the most recent sample M2-008 is, with $15.6 \pm 6.7^{\circ} \mathrm{C}$, considerably higher (but not outside of $1 \sigma$ uncertainties) than the annual mean temperature of Late Holocene reported from Hinterburgsee (around $10{ }^{\circ} \mathrm{C}$; Heiri et al., 2003). However, the NGT of M2-008 also exceeds temperature measurements in Milandre Cave between 2008 and 2010. Therefore, it must be assumed that M2-008 has not only significantly lost $\mathrm{Ne}$, Ar, and $\mathrm{Kr}$, but was also subject to substantial Xe loss.

\subsection{The significance of temperature ranges at given times in the past}

Generally, the different paleo-temperature records in Fig. 4 agree well, both in absolute temperature values as well as in temperature variations between different time periods. However, the various temperature estimates at specific times in the past cover a considerable range. For instance, the estimated annual mean Allerød temperature in the studied area range between 1 and $8{ }^{\circ} \mathrm{C}$. At the transition Younger 
Dryas - Holocene, the observed temperature spread is even larger. We are tempted to argue that the

481

482

483

484

485

486

487

488

489

490

491

492

493

494

495

496

497

498 observed temperature range / scatter neither has a paleo-climatic meaning, nor does it indicate any systematic problem with one or other method to reconstruct past temperatures. Instead we emphasize that the systematic uncertainties associated with the applied temperature scaling (e.g. conversion of summer / July temperature to annual mean temperature) cannot be properly quantified and might, therefore, account for the observed temperature spread. Possible causes of these uncertainties are discussed in the following paragraphs.

A major uncertainty is introduced if different 'types of temperatures' (i.e. July or summer temperatures) are converted to annual mean temperatures (or vice versa) as was required to directly compare that different data sets. Due to the lack of robust estimates of the difference of summer / July temperature and the respective annual mean temperature ( $\Delta T$, see above), the $\Delta T s$ used in our study are estimated from the present situation in Switzerland or from more continental regions showing a larger annual temperature variation (see section 4.2.). Although the associated error of the applied temperature scaling is large, small-scale regional or temporal variability of the paleo- $\Delta T$ might still not fully cover the prevailing $\Delta T$ in the past.

A similar argument holds for the applied summer and annual mean adiabatic lapse rates of 0.6 and 0.5 ${ }^{\circ} \mathrm{C} / 100 \mathrm{~m}$, which we used to scale the temperature estimates to the same altitude, i.e. that of the Milandre Cave. We assume that these present-day lapse rates were not markedly different from those in the past, i.e. that they are insensitive with respect to different climatic studies of the past. This assumption is supported with results of a recently comprehensive study (Mauri et al., 2015), which used the presentday topographic lapse rate to reconstruct past climate on different landscapes. However, the uncertainty introduced by this assumption cannot be easily quantified and is, therefore, not accounted for by our applied scaling exercise.

Another well-known difficulty is to properly tune different records in terms of chronology. Most studies do not explicitly give information on different records (sediment cores, stalagmites), different time resolutions and age uncertainties. Neither, the numbers of tie points where absolute ages are available is 
essential for the accuracy of the respective age model, were not available. In addition, methods to reconstruct past temperatures require different amounts of sample material, i.e. each sample integrates over a different time range, which constrains the direct comparability of different data. Therefore, in our point of view, the large deviation of the observed temperature estimates for the Younger Dryas - Holocene transition simply reflects an irregular temporal trend of the past temperature increase towards the early Holocene resulting from comparing different climatic records.

\subsection{Loss of noble gases from recently precipitated stalagmite samples}

As discussed above, the youngest sample (M2-008) has experienced substantial loss of noble gases from its water inclusions. A more moderate loss of noble gases is also observed for the second youngest sample (M2-047). As discussed in section 3.2.2., noble gas loss most likely occurs during sample processing under vacuum conditions. In contrast, samples older than 10’000 years BP have completely retained water and noble gases in their inclusions and thus yield reliable NGTs. A similar observation has been made earlier on a large NGT data set of very old and recently precipitated stalagmite samples from Borneo (Meckler et al., 2013, 2015). Therefore, we hypothesize that a reduced retentivity for noble gases in recent stalagmite samples during sample processing is a general feature of recent calcite precipitates. In spite of the fact that the available NGT data set on recent stalagmite samples is still very small, we conclude that some kind of secondary diagenetic process occurring later than the original trapping of the fluid inclusion strengthen (e.g. by progressive cementation) the crystal fabric of the stalagmite with increasing time. However, because such a secondary process is not yet operational for the most recent part of the stalagmite, the calcite structure of the recently precipitated stalagmite is still weak and thus is prone to gas (and water) loss during noble gas extraction by the CVCS technique. Frisia et al. (2018) add some evidence to our hypothesis that early diagenetic processes operate within the first few centimeters below the active growth layer. In this uppermost zone, fluid can circulates within speleothems and change the properties of the original calcite fabrics (see more details: Frisia et al., 2018). This early diagenetic processes seem to influence the growth of the calcite, and thus might have profound effects on preservation of the initial crystal structure. Therefore, we speculate that such calcite 
structure seems not to 'strong / rigid' enough to preserve the original noble gases signature within fluid inclusions.

\section{Summary}

We have applied for the first time our CVCS technique to determine noble gas temperatures in a stalagmite grown under cold climatic conditions. Determination of past cave temperatures based on noble gas concentrations in speleothem fluid inclusions by using the CVCS system has so far only been shown to be reliable for stalagmites grown under warm / hot climatic conditions. The investigated stalagmite M2 indicates annual mean temperatures in the Milandre Cave (Swiss Jura Mountains) of $2.2 \pm 1.8{ }^{\circ} \mathrm{C}$ (average of M2-214 and -199) at the end of the Allerød Interstadial and drop to $0 \stackrel{+}{+} 2.6{ }^{\circ} \mathrm{C}$ (average of M2-192 and -179) in the early part of the Younger Dryas. These temperatures indicate conditions near to the freezing point of water during the first part of the Younger Dryas with reduced stalagmite growth. The mean annual temperature increases towards the Younger Dryas - Holocene transition to $6.3 \pm 2.3$ ${ }^{\circ} \mathrm{C}$, and a temperature of around $8.7 \pm 2.7^{\circ} \mathrm{C}$ is inferred from a late Holocene sample, very similar to modern cave air temperatures of $9.56 \pm 0.15{ }^{\circ} \mathrm{C}$ at the sampling site of stalagmite M2. Our determined NGTs agree very well with (scaled) annual mean temperatures derived from pollen, chironomid, and cladoceran assemblages from sediment cores of lakes and from sites located within a $120 \mathrm{~km}$ radius from the Milandre Cave. Differences between the various temperature reconstructions are mainly attributed to the difficulty of converting the published paleo-temperatures to annual mean temperatures, and to the difficulty of arranging the temperatures from various paleo-climate records in accurate chronological order. However, we note that the rescaling exercise is only used to validate our temperature reconstruction of noble gases with other temperature reconstructions. We are well aware that the details of rescaling different temperature reconstruction techniques to a common basis (e.g. summer temperature to annual mean temperature) calls for further investigation. Gas losses observed in two recently precipitated stalagmite samples are most likely experimentally caused during sample processing. The depletion is too substantial to derive meaningful temperature information from the resulting noble gas data. Reduced retentivity for noble gases in recently precipitated stalagmite samples is not only observed in the investigated stalagmite M2, but also in stalagmites from Borneo (Meckler et al., 2015). Thus, this 
559 phenomena seems to be an inherent feature of recently precipitated stalagmite samples. We hypothesize 560 that the underlying cause might be related to an incomplete diagenetic processes that stabilizes or seals 561 the structure of the calcite fabric during stalagmite growth. This observation calls for further investiga562 tion to clarify this issue in order to evaluate if such constraint not only limits NGT determination, but 563 also affects other methods being used to retrieve past climate information from fluid inclusion of stal564 agmites (e.g. $\delta \mathrm{D}$ analysis in water inclusions).

565 With the exception of the recently precipitated stalagmite samples, with this study we have now estab566 lished noble gas thermometry as a valid and operational tool to reconstruct paleo-temperatures for stalagmites grown under a large range of climatic conditions from hot - arid (Vogel et al., 2013a) over hot 568 - humid (Meckler et al., 2013, 2015) to cold environmental conditions (this study). 


\section{Acknowledgments}

570 We would like to thank A. Süesli, D. Niederer and U. Menet for their constant and highly appreciated

571 support in the noble gas laboratory. Frequent discussions with all members of the Environmental Isotope

572 group at Eawag and the members of the Stalclim project are greatly acknowledged. We also thank A.

573 Baker and one anonymous reviewer for their helpful comments on an earlier version of our work. This

574 work was supported by the Swiss National Science Foundation (grant no. 200021_155891 / 1). 
Aeschbach-Hertig, W., Peeters, F., Beyerle, U., Kipfer, R. (1999) Interpretation of dissolved atmospheric noble gases in natural waters. Water Resources Research 35, 2779-2792. https://doi.org/10.1029/1999WR900130.

Affek, H. P., Bar-Matthews, M., Ayalon, A., Matthews, A. and Eiler, J. M. (2008) Glacial/interglacial temperature variations in Soreq cave speleothems as recorded by "clumped isotope" thermometry, Geochim. Cosmochim. Acta 72, 5351-5360. https://doi.org/10.1016/j.gca.2008.06.031.

Affolter, S., Fleitmann, D., Leuenberger, M. (2014) New-on-line method for water isotope analysis of speleothem fluid inclusions using laser absorption spectroscopy (WS-CRDS). Clim. Past 10, 1291-1304. https://doi.org/10.5194/cp-10-1291-2014.

Affolter, S., Häuselmann, A.D., Fleitmann, D., Häuselmann, P., Leuenberger, M. (2015) Triple isotope $\left(\delta \mathrm{D}, \delta^{17} \mathrm{O}, \delta^{18} \mathrm{O}\right)$ study on precipitation, drip water and speleothem fluid inclusions for a Western Central European cave (NW Switzerland). Quat. Sci. Rev. 127, 73-89. https://doi.org/10.1016/j.quascirev.2015.08.030.

Ballentine, C.J., Hall, C.M. (1999) Determining paleotemperature and other variables by using an errorweighted, nonlinear inversion of noble gas concentrations in water. Geochim. Cosmochim. Acta 63, 2315-2336. https://doi.org/10.1016/S0016-7037(99)00131-3.

Beyerle, U., Aeschbach-Hertig, W., Imboden, D.M., Baur, H., Graf, T., Kipfer, R. (2000) A mass spectrometric system for the analysis of noble gases and tritium from water samples, Environ. Sci. Technol. 34, 2042-2050. https://doi.org/10.1021/es990840h.

Braillard, L. (2006) Morphogenèse des vallées sèches du Jura tabulaire d'Ajoie (Suisse): role de la fracturation et étude des remplissages quaternaires, Département de Géosciences, Géologie et Paléontologie. Université de Fribourg (Suisse), p. 224.

Breitenbach, S.F.M., Rehfeld, K., Goswami, B., Baldini, J.U.L., Ridley, H.E., Kennett, D.J., Prufer, K.M., Aquino, V.V., Asmerom, Y., Polyak, V.J., Cheng, H., Kurths, J., Marwan, N. (2012) Constructing Proxy Records from Age models (COPRA). Clim. Past 8, 1765-1779. https://doi.org/10.5194/cp-8-1765-2012.

Brennwald, M.S., Vogel, N., Scheidegger, Y., Tomonaga, Y., Livingstone, D.M., Kipfer, R. (2013a) Noble gases as environmental tracers in sediment porewaters and in stalagmite fluid inclusions, in: Burnard, P. (Ed.), The noble gases as geochemical tracers. Springer, Berlin Heidelberg, pp. 123-153. https://doi.org/10.1007/978-3-642-28836-4 6.

Brennwald, M.S., Vogel, N., Figura, S., Vollmer, M.K., Langenfelds, R.L., Steele, L.P., Maden, C., Kipfer, R. (2013b) Concentrations and isotope ratios of helium and other noble gases in the Earth's atmosphere during 1978-2011. Earth Planet. Sc. Lett. 366, 27-37. https://doi.org/10.1016/j.epsl.2013.01.039.

Cheng, H., Lawrence Edwards, R., Shen, C.-C., Polyak, V.J., Asmerom, Y., Woodhead, J., Hellstrom, J., Wang, Y., Kong, X., Spötl, C., Wang, X., Calvin Alexander Jr, E. (2013) Improvements in ${ }^{230} \mathrm{Th}$ dating, ${ }^{230} \mathrm{Th}$ and ${ }^{234} \mathrm{U}$ half-life values, and U-Th isotopic measurements by multi-collector inductively coupled plasma mass spectrometry. Earth Planet. Sc. Lett. 371-372, 82-91. https://doi.org/10.1016/j.eps1.2013.04.006.

de Magalhães, H. P., Brennwald, M. S., \& Kipfer, R. (2017) Diverging effects of isotopic fractionation upon molecular diffusion of noble gases in water: mechanistic insights through ab initio molecular dynamics simulations. Environmental Science: Processes \& Impacts 19, 405-413. https://doi.org/10.1039/C6EM00614K.

Fairchild, I.J., Smith, C.L., Baker, A., Fuller, L., Spötl, C., Mattey, D., McDermott, F., E.M.I.F. (2006) Modification and preservation of environmental signals in speleothems. Earth-Science Reviews 75, 105-153. https://doi.org/10.1016/j.earscirev.2005.08.003.

Fairchild, I.J., Baker, A. (2012) Speleothem science. From process to past environments. Wiley-Blackwell, Oxford, UK. https://doi.org/10.1002/9781444361094.ch7.

Frisia, S., Borsato, A., \& Hellstrom, J. (2018). High spatial resolution investigation of nucleation, growth and early diagenesis in speleothems as exemplar for sedimentary carbonates. Earth-Science Reviews, 178, 68-91. https://doi.org/10.1016/j.earscirev.2018.01.014 
Heiri, O., Lotter, A.F., Hausmann, S., Kienast, F. (2003) A chironomid-based Holocene summer air temperature reconstruction from the Swiss Alps. The Holocene 13, 477-484. https://doi.org/10.1191/0959683603hl640ft.

Heiri, O., Millet, L. (2005) Reconstruction of Late Glacial summer temperatures from chironomid assemblages in Lac Lautrey (Jura, France). Journal of Quarternary Science 20, 33-44. https://doi.org/10.1002/jqs.895.

Häuselmann, A. D. (2015) Late Quaternary and Holocene paleoclimate and paleoenvironmental reconstruction-a multi-proxy approach on Swiss speleothems, PhD Thesis, University of Bern, Bern, Switzerland, $178 \mathrm{p}$.

Jaffey, A.H., Flynn, K.F., Glendenin, L.E., Bentley, W.C., Essling, A.M. (1971) Precision measurement of half-lives and specific activities of ${ }^{235} \mathrm{U}$ and ${ }^{238} \mathrm{U}$. Phys. Rev. C 4, 1889-1906.

Jung, M., Wieser, M., von Oehsen, A. and Aeschbach-Hertig, W. (2013) Properties of the closed-system equilibration model for dissolved noble gases in groundwater, Chem. Geol. 339: 291-300. https://doi.org/10.1103/PhysRevC.4.1889.

Jähne, B., Heinz, G., Dietrich, W. (1987) Measurement of the diffusion coefficients of sparingly soluble gases in water. J Geophys Res 92, 10767-10776. https://doi.org/10.1029/JC092iC10p10767.

Kipfer, R., Aeschbach-Hertig, W., Peeters, F., Stute, M. (2002) Noble gases in lakes and ground waters, in: Porcelli, D., Ballentine, C.J., Wieler, R. (Eds.), Noble gases in geochemistry and cosmochemistry. The Mineralogical Society of America, Washington, DC, pp. 615-700. https://doi.org/10.2138/rmg.2002.47.14.

Kluge, T., Marx, T., Scholz, D., Niggemann, S., Mangini, A., Aeschbach-Hertig, W. (2008) A new tool for paleoclimate reconstruction: noble gas temperatures from fluid inclusions in speleothems. Earth Planet. Sci. Lett. 269, 408-415. https://doi.org/10.1016/j.eps1.2008.02.030.

Krüger, Y., Marti, D., Staub, R.H., Fleitmann, D. and Frenz, M. (2011) Liquid-vapour homogenisation of fluid inclusions in stalagmites: Evaluation of a new thermometer for palaeoclimate research, Chem. Geol. 289, 39-47. https://doi.org/10.1016/j.chemgeo.2011.07.009.

Livingstone, D.M., Lotter, A.F., Walker, I.R. (1999) The decrease in summer surface water temperature with altitude in Swiss alpine lakes: a comparison with air temperature lapse rates. Arctic, Antarctic, and Alpine Research 31, 341-352. https://doi.org/10.2307/1552583.

Lotter, A.F., Birks, H.J.B., Eicher, U., Hofmann, W., Schwander, J., Wick, L. (2000) Younger Dryas and Allerød summer temperatures at Gerzensee (Switzerland) inferred from fossil pollen and cladoceran assemblages. Palaeogeography, Palaeoclimatology, Palaeoecology 159, 349-361. https://doi.org/10.1016/S0031-0182(00)00093-6.

Magny, M., Guiot, J., Schoellammer, P. (2001) Quantitative reconstruction of the Younger Dryas to mid-Holocene paleoclimates at Le Locle, Swiss Jura, using pollen and lake-level data. Quarternary Research 56, 170-180. https://doi.org/10.1006/qres.2001.2257.

Mazor, E. (1972) Paleotemperature and other hydrological parameters deduced from gas dissolved in groundwaters, Joedan Rift Valley, Israel. Geochim Cosmochim Acta36(12), 1321-1336. https://doi.org/10.1016/0016-7037(72)90065-8.

Mauri, A., Davis, B.A.S., Collins, P.M., Kaplan, J.O. (2015) The climate of Europe during the Holocene: a gridded pollen-based reconstruction and its multi-proxy evaluation. Quat. Sci. Rev. 112, 109127. https://doi.org/10.1016/j.quascirev.2015.01.013.

Meckler, A.N., Affolter, S., Dublyansky, Y., Krüger, Y., Vogel, N., Bernasconi, S., Fleitmann, D., Frenz, M., Kipfer, R., Leuenberger, M., Spötl, C. (2013) Comparison of new temperature proxies in stalagmites - A step towards quantitative climate reconstruction, Conference on Isotopes of Carbon, Water, and Geotracers in Paleoclimate Research, Bern, Switzerland.

Meckler, A.N., Affolter, S., Dublyanski, Y.V., Krüger, Y., Vogel, N., Bernasconi, S.M., Frenz, M., Kipfer, R., Leuenberger, M., Spötl, C., Carolin, S., Cobb, K.M., Moerman, J., Adkins, J.F., Fleitmann, D. (2015) Glacial-interglacial temperature change in the tropical West Pacific: a comparison of stalagmite-based paleo-thermometers. Quat. Sci. Rev. 127, 90-116. https://doi.org/10.1016/j.quascirev.2015.06.015.

Press, W.H., Flannery, P.F., Teukolsky, S.A., Vetterling, W.T. (1986) Numerical Recipes. Cambridge University Press, New York.

Scheidegger, Y.M., Baur, H., Brennwald, M.S., Fleitmann, D., Wieler, R., Kipfer, R. (2010) Accurate analysis of noble gas concentrations in small water samples and its application to fluid inclusions in stalagmites. Chem. Geol. 272, 31-39. https://doi.org/10.1016/j.chemgeo.2010.01.010. 
Scheidegger, Y.M., Brennwald, M.S., Fleitmann, D., Jeannin, P. Y., Wieler, R., Kipfer, R. (2011) Determination of Holocene cave temperatures from $\mathrm{Kr}$ and $\mathrm{Xe}$ concentrations in stalagmite fluid inclusions. Chem. Geol. 288, 61-66. https://doi.org/10.1016/j.chemgeo.2011.07.002.

Schmassmann, S. (2010) Speleothem-based climate and environmental reconstruction: a pilot study in the Swiss Jura Mountains, Philosophisch naturwissenschaftliche Fakultät. Universität Bern, p. 149.

Spadin, F., Marti, D., Hidalgo-Staub, R., Rička, J., Fleitmann, D., and Frenz, M. (2015) Technical Note: How accurate can stalagmite formation temperatures be determined using vapour bubble radius measurements in fluid inclusions?, Clim. Pas, 11, 905-913. https://doi.org/10.5194/cp-11-905$\underline{2015}$.

Thompson, P. (1973) Spelechronology and late Pleistocene climates inferred from O, C, H, U and Th isotpic abundance in speleothems. PhD thesis, McMaster Univ., Hamilton, Ontario. 340 pp.

Tyroller, L., Tomonaga, Y., Brennwald, M. S., Ndayisaba, C., Naeher, S., Schubert, C., North, R. P., and Kipfer. R. (2016) Improved method for the quantification of methane concentrations in unconsolidated lake sediments. Environ. Sci. Technol. 50: 7047-7055. https://doi.org/10.1021/acs.est.5b05292.

Vogel, N., Brennwald, M.S., Fleitmann, D., Wieler, R., Maden, C., Süsli, A., Kipfer, R. (2013a) A combined vacuum crushing and sieving (CVCS) system designed to determine noble gas paleotemperatures from stalagmite samples. Geochemistry, Geophysics, Geosystems 14, 2432-2444. https://doi.org/10.1002/ggge.20164.

Vogel, N., Scheidegger, Y., Brennwald, M.S., Fleitmann, D., Figura, S., Wieler, R., Kipfer, R. (2013b) Stalagmite water content as a proxy for drip water supply in tropical and subtropical areas. Clim. Past 8, 1-9. https://doi.org/10.5194/cpd-8-2893-2012.

von Grafenstein, U., Erlenkeuser, H., Müller, J., Jouzel, J., Johnsen, S. (1998) The cold event 8200 years ago documented in oxygen isotope records of precipitation in Europe and Greenland. Climate Dynamics 14, 73-81. https://doi.org/10.1007/s003820050210.

Wick, L. (2000) Vegetational response to climate changes recorded in Swiss Late Glacial lake sediments. Palaeogeography, Palaeoclimatology, Palaeoecology 159, 231-250. https://doi.org/10.1016/S0031-0182(00)00087-0.

Zhang, R., Schwarcz, H.P., Ford, D.C., Schroeder, F.S., and Beddows, P.A. (2008) An absolute paleotemperature record from 10 to $6 \mathrm{ka}$ inferred from fluid inclusion $\mathrm{D} / \mathrm{H}$ ratios of a stalagmite from Vancouver Island, British Columbia, Canada, Geochim. Cosmochim. Act, 72, 1014-1026. https://doi.org/10.1016/j.gca.2007.12.002. 